\title{
Analysis of Building Position and Orientation to Assess the Building Vulnerability to Landslide Through the Interpretation of 2D Small Format Aerial Photo
}

\author{
(Case Study in Bompon Catchment, Magelang Regency)
}

\author{
Boby Setyawan \\ Yogyakarta, Indonesia \\ Junun Sartohadi \\ Geography Faculty \\ Universitas Gadjah Mada \\ Yogyakarta, Indonesia \\ Danang Sri Hadmoko \\ Geography Faculty \\ Universitas Gadjah Mada \\ Yogyakarta, Indonesia
}

Geo-Information for Spatial Planning and Disaster Risk Management

Graduate School of Universitas Gadjah Mada

Corresponding email: bobysetyawan_geografium@yahoo.com

\begin{abstract}
Bompon catchment is one of area in Central Java Province that has an intense of landslide occurrence. Bompon catchment has a hilly area and a thick layer of soil with clay texture. A landslide was triggered by the thick layer of soil and also the community activities that cut the slopes. The objective of this research was to assess the physical vulnerability of buildings toward the landslide. This research was conducted semiquantitatively. The vulnerability assessments were conducted through the interpretation of $2 \mathrm{D}$ small format aerial photograph. The population of this research was the buildings in Bompon catchment. The data was validated through the intensive field survey. There were 36 landslide events that has identified through the interpretation of small format aerial photo and validated through the intensive field survey. The result of building vulnerability toward landslide analysis indicated that the highest percentage of vulnerability $(44 \%)$ was included in moderate level. The vulnerability levels of the buildings are distributed spatially as a cluster. The high vulnerability level was influenced by the position and orientation of the building to landslide.
\end{abstract}

Keywords-Small format aerial photo, landslide, vulnerability, building.

\section{INTRODUCTION}

Indonesia has a characteristic of mountainous and hilly area, so it can triggered landslide occurrence. Landslide is one of most frequent disaster that occur in the world, exposing many social and economic losses each year in the different geographical region (Motamedi, 2013).the increase of population followed by needs of housing and economic factors encourage the community to occupy a less habitable location such as the hilly with a steep slopes area. That condition caused peoples threatened by landslides. Losses that may be suffered by the community can be reduced by the information of landslide maps and building vulnerability as the main element at risk in Bompon catchment.

This study is examines the building vulnerability to landslide in Bompon catchment. Bompon catchment is one of area in central java that has intensity of landslide occurrence. Bompon catchment was located in Magelang regency, Central of Java province. Bompon catchment has a hilly area with a steep slope area. Bompon catchment consist of very thick of soil layer that affected by the alteration and mechanical weathering of bedrock. The surface material and the basement material are consist of clay, and Sumbing volcanic ash. The condition of the area was triggered to landslides event. 


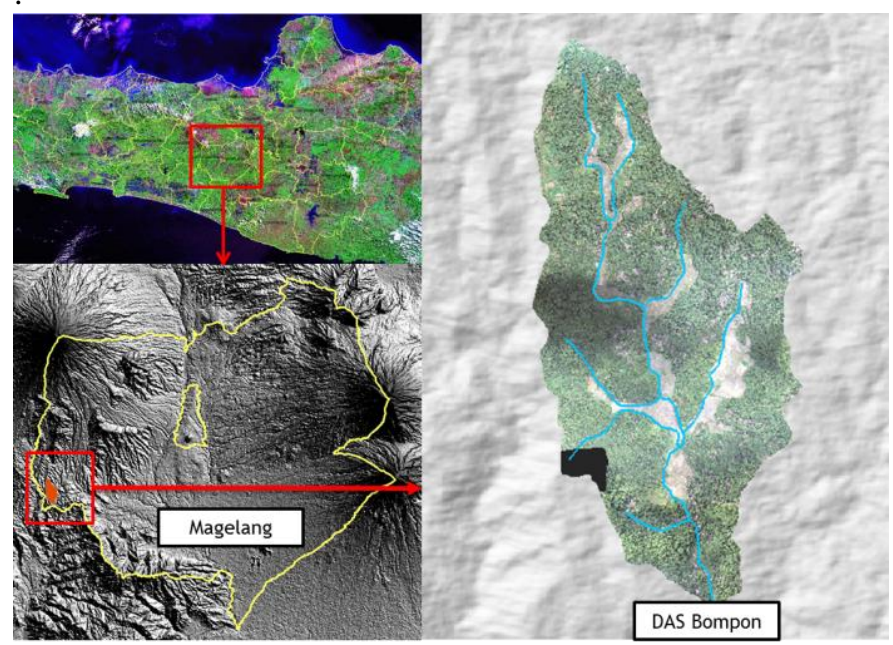

Fig 1. The research site

Most of physical vulnerability analysis was generated through the intensive field survey. The building identification through the interpretation of remote sensing was very less. The parameters used to assess the vulnerability level are usually only on the physical appearance of the building. The analysis of building position and orientation to landslide were not used yet. The objection of this research is to assess the building vulnerability through the interpretation of small format aerial photo by involving the parameters of building position and orientation to landslide.

\section{METHOD}

This research was conducted as quantitative descriptively. The population of this research was the buildings in Bompon catchment. The sampling method is census. The whole buildings and its vulnerability parameters were identified through the interpretation of small format interpretation. The total number of samples obtained by the 733 unit building.

\section{A. Landslide Inventory Analysis}

Landslide inventory was conducted through the integrated interpretation of small format aerial photo and the Morphology unit. The interpretation keys that used are the color, form, and pattern. The analysis result then validated by the intensive field survey.

\section{B. Building Identification Through the Small Format Aerial Photo}

The identification of the building and its vulnerability parameters was generated through the interpretation of small format aerial photo. The keys interpretation used are color, form, pattern, and association.

\section{Building Vulnerability to Landslide}

Buildings vulnerability assessment was done through the small format aerial photo interpretation. The interpretation key used to identify the characteristics of the building were the tone/color, shape, association, site, and size.
Physical elements of the building consists of structure, roofing material, wall material, and building shape. Indicators of the physical elements of the building identified by it appearance on aerial photographs. Building position was identified through the landslide path length. The buildings orientation was identified based on its direction toward the landslides.

The vulnerability method used in this research was the semi-quantitative method. A semi-quantitative method was used the score and weight on the range of $0-1$. Score 0 was represent the lowest vulnerability level, while score 1 was represent the highest vulnerability level. Based on the consideration and adjustment from the research location, the vulnerability indicator with its criteria was conducted. The vulnerability level was classified into 3 levels, high, moderate, and low.

TABLE I. The Variable Assumption of Building Vulnerability to Landslide

\begin{tabular}{|c|c|c|c|c|}
\hline No & Indicator & $\begin{array}{l}\text { Wight } \\
\text { (W) }\end{array}$ & Criteria & $\begin{array}{l}\text { Score } \\
(\mathrm{S})\end{array}$ \\
\hline 1. & $\begin{array}{l}\text { Building } \\
\text { Structure }\end{array}$ & 0.1 & $\begin{array}{l}\text { 1. Limasan } \\
\text { 2. Kampung } \\
\text { 3. Pangganpe }\end{array}$ & $\begin{array}{l}0.4 \\
0.6 \\
0.8\end{array}$ \\
\hline 2. & $\begin{array}{l}\text { Roofing } \\
\text { Material }\end{array}$ & 0.1 & $\begin{array}{l}\text { 1. Zinc/Asbestos } \\
\text { 2. Roof tile }\end{array}$ & $\begin{array}{l}0.4 \\
0,6 \\
\end{array}$ \\
\hline 3. & Wall Material & 0.2 & $\begin{array}{l}\text { 1. Brick } \\
\text { 2. Wood/Bamboo }\end{array}$ & $\begin{array}{l}0.3 \\
0.8\end{array}$ \\
\hline 4. & $\begin{array}{l}\text { Building } \\
\text { Position }\end{array}$ & 0.3 & $\begin{array}{l}\text { 1. } 1.5 \mathrm{~L}-2 \mathrm{~L} \\
\text { 2. } 1 \mathrm{~L}-1.5 \mathrm{~L} \\
\text { 3. } 0.5 \mathrm{~L}-1 \mathrm{~L} \\
\text { 4. } 0-0.5 \mathrm{~L}\end{array}$ & $\begin{array}{l}0,1 \\
0,3 \\
0.6 \\
0.8\end{array}$ \\
\hline 5. & $\begin{array}{l}\text { Building } \\
\text { Orientation }\end{array}$ & 0.2 & $\begin{array}{l}\text { 1. } 180^{\circ} \\
\text { 2. } 0^{\circ} \\
\text { 3. } 45^{\circ} / 135^{\circ} / 225^{\circ} / 315^{\circ} \\
\text { 4. } 90^{\circ} / 270^{\circ}\end{array}$ & $\begin{array}{l}0.2 \\
0.3 \\
0.5 \\
0.7\end{array}$ \\
\hline 6. & $\begin{array}{l}\text { Building } \\
\text { Shape }\end{array}$ & 0.1 & $\begin{array}{l}\text { 1. Irreguler } \\
\text { 2. Reguler }\end{array}$ & $\begin{array}{l}0.4 \\
0.6\end{array}$ \\
\hline
\end{tabular}

Source: modification of van Westen (2005), De León (2006), dan Eidsvig dkk

$\mathrm{Nb}$ : $\mathrm{L}$ was the length of the landlise

Total vulnerability was conducted by this formula: $\mathrm{V}=\Sigma(B \times S)$ Equation 1

Interval class was conducted by this formula: Interval Class $=\frac{\text { highest score-lowest score }}{\text { total class }}$........ Equation2

\section{FINDING AND DISCUSSION}

\section{A. Landslide Inventory Analysis}

Based on interpretation through the small format aerial photo integrated with the morphology unit, it was identified 34 landslides. The identified landslides mostly are landslide inactive with a wide area. The result of the analysis then validated through the intensive field survey. The field survey objective was to validate the occurrence of landslide in the real site. The field survey also identified the landslide activeness, landslide type, and also the landslide body. The result of the field survey is shown at Fig.2. 


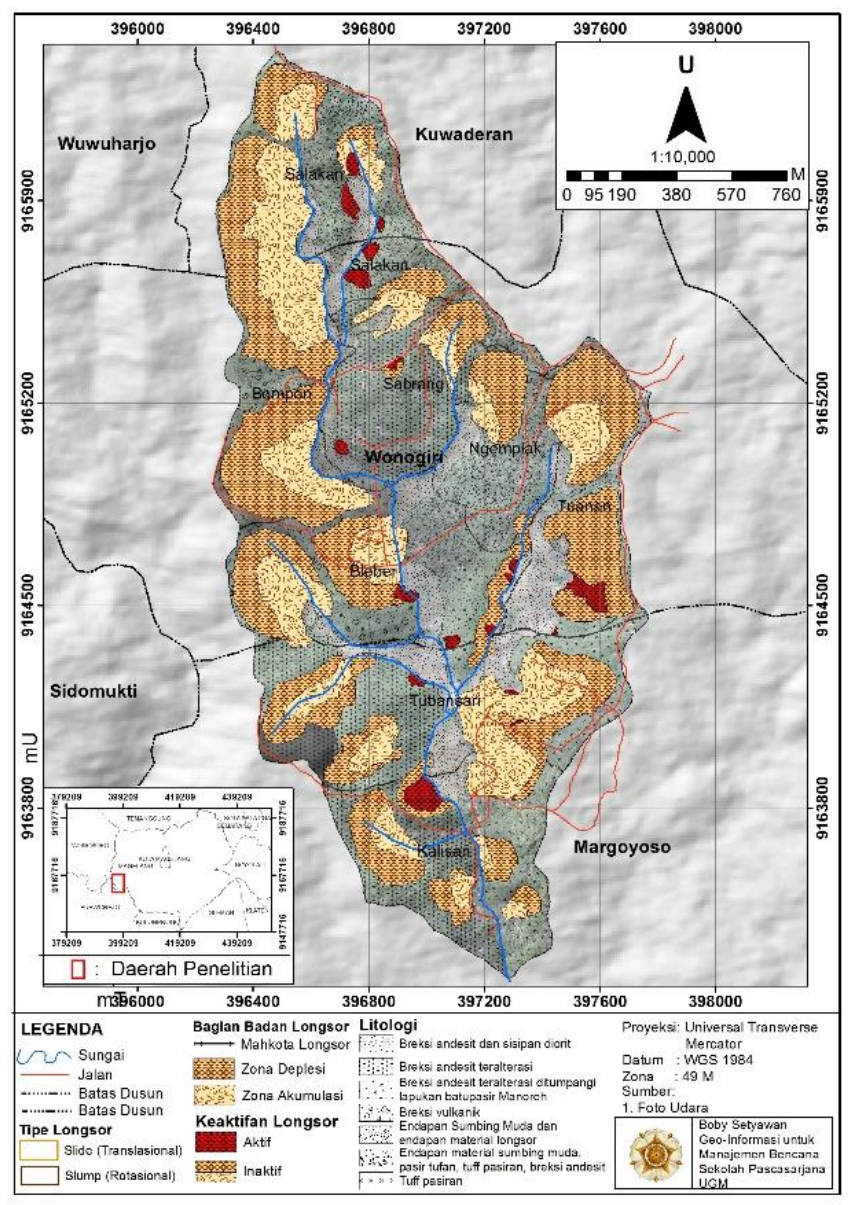

Fig 2. Landslide Inventory

The result of the landslide inventory analysis was found 36 landslide events in Bompon Catchment. The landslides inventory consists of 18 active landslides and 18 inactive landslides. Most of the landslides types are rotational slide. The landslide location distributed spread on all part of Bompon catchment, especially at the hilly area with a steep slope. The active landslide mostly was founded at the lower slope with slope gradient more than $26^{\circ}$.

Active landslide triggered by the river flow and anthropogenic activity. Active landslide at the lower part of Bompon catchment was triggered by the river that flow under the slope. The rivers that flows cut the slope make the slope unstable and then triggering landslide. Active landslide also triggered by the anthropogenic activity. Buildings and roads sometimes build by cutting the slope, so it can triggering landslide. By the lithology, active landslide mostly occurred in the areas experienced an alteration on its bedrock. The weathering process occurs intensively on the alteration bedrock, so it makes the soil layer getting very thick. The very thick layer of soil with the steep slope can triggering landslide.

\section{B. Building Identification Through the Small Format Aerial Photo Interpretation}

The element at risk in this research is the building. Building data conducted through the interpretation of $2 \mathrm{D}$ small format aerial photo. The building identified through its appearance in colors, form, and association. Each form of building has a different characteristic. The vulnerability parameters can be assess by building characteristic. Table 2 is shows 6 types of building in Bompon catchment.

TABLE II. BUILDING TYPES IN BOMPON CATCHMENT

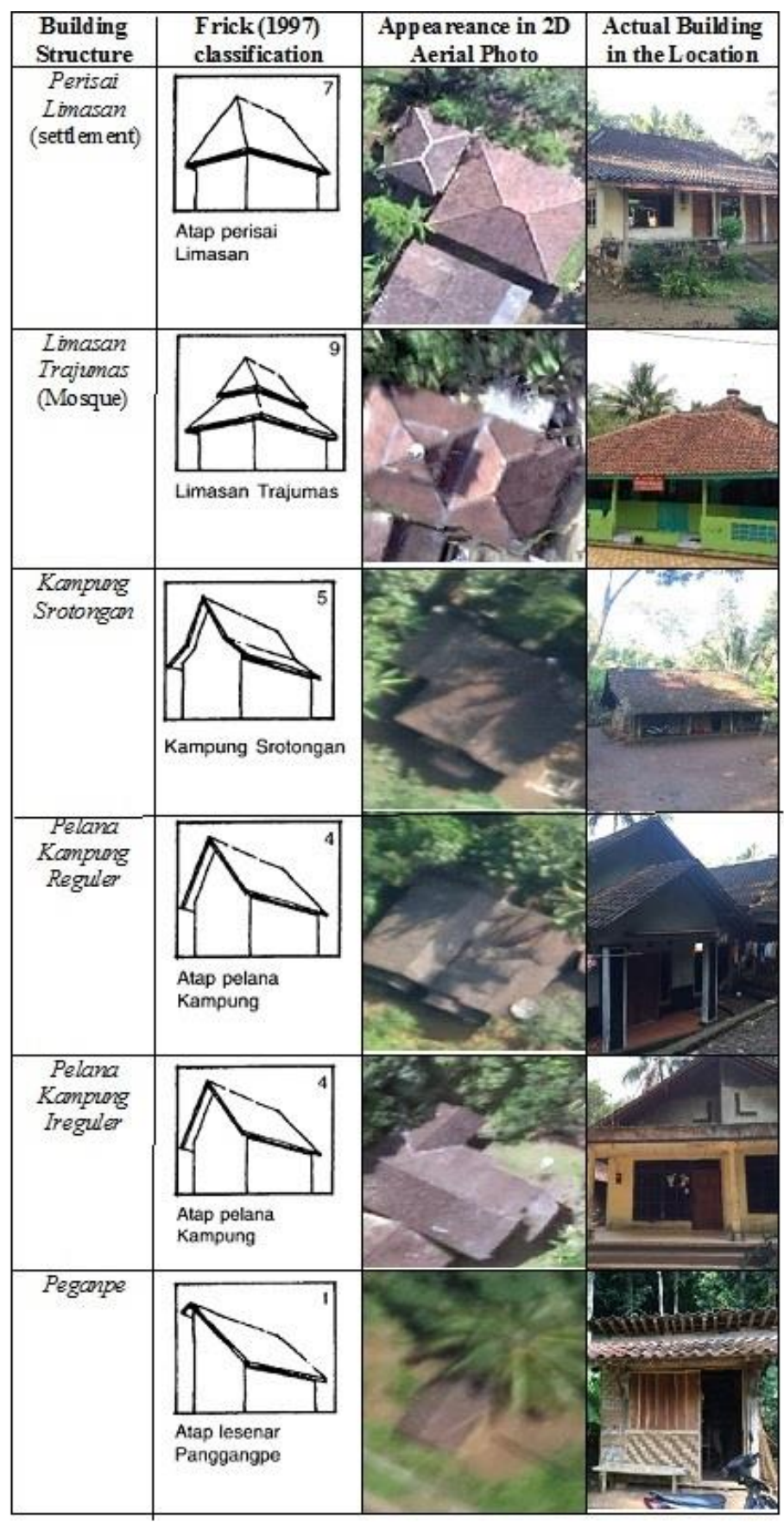


The building in Bompon catchment has a similar form. Almost buildings have one floor with dominant structure of "Kampung" building. Kampung is a simple building structure in a regular form. Kampung building structure usually type for settlement. Buildings in Bompon catchment also consist of Mosque, School, Security building, and sheep fold.

Visual interpretation method has proven that it can identified buildings from small format aerial photo effectively. Visual interpretation method can saving time, cost, and energy to identify building characteristic in a large number. This result also supported by the previous research from Saputra (2012). Saputra (2012) found that building visual interpretation can effectively predict building vulnerability to earthquake in Pleret, Yogyakarta.

\section{Building Vulnerability to Landslide Analysis}

Building vulnerability to landslide analysis conducted semiquantitatively. The parameters used to assess the building vulnerability are the building structure, roof material, wall material, building position from the slope, building orientation from the slope, and building regularity form (Table 1). The score and weight given as the parameters identified from small format aerial photo interpretation. The number of buildings based on its vulnerability parameter is shown in Table 3 .

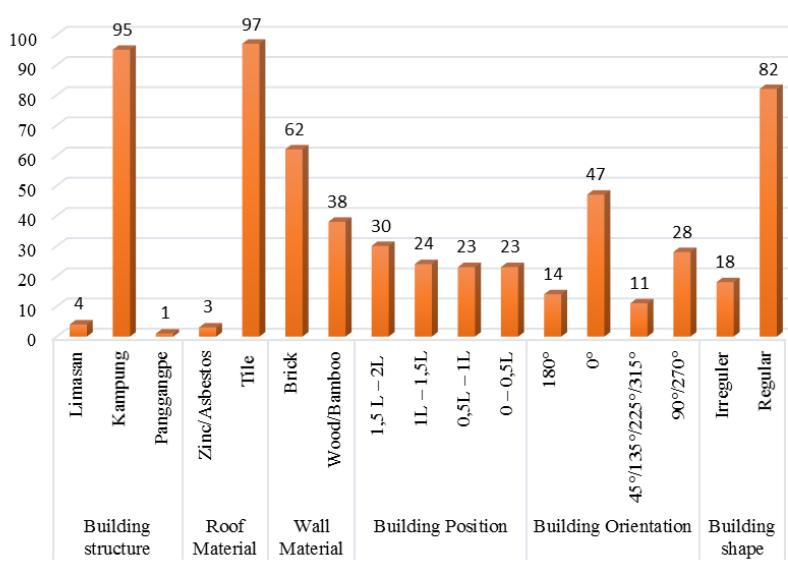

Fig 3. The result of the vulnerability parameters assessment

From the result on Table 3, each parameter given by score and weight as shown in Table 1 . The result of the physical building vulnerability analysis to landslide was showed that from 733 buildings unit, most of the building classified as moderate levels. The high vulnerability levels was covered 185 (25\%) buildings. The moderate levels was covered $331(45 \%)$ buildings. The low levels was covered 217 (30\%) buildings. based on its administrative in Bompon Catchment, buildings with a high vulnerability levels in Margoyoso Village were 110 units, in Wonogiri Village were 68 units, and in Kuwaderan Village were 5 units. Buildings with a moderate vulnerability levels in Margoyoso Village were 71 units, in Wonogiri Village were 227 units, and in Kuwaderan Village were 31 units. Buildings with a low vulnerability levels in Margoyoso Village were 102 units, in Wonogiri Village were 104 units, and in
Kuwaderan Village were 11 units. The spatial pattern of the buildings in each levels was clustered. The cluster pattern indicates that building vulnerability was influenced by the position and orientation of the building to landslide.

In this research, the building vulnerability was broadly influenced by the position of the buildings from the slope. Building association to slope is the main triggering factor in building damage when the landslide occurs. Building position and building orientation to slope are the main parameters inputted as the parameter of building physical vulnerability. Those parameters can complete the previous research about the parameter of physical building vulnerability. The previous research only used the parameters of wall material, roof material, and also floor material (Astuti, 2011; Muis, 2012; Maitri, 2013).

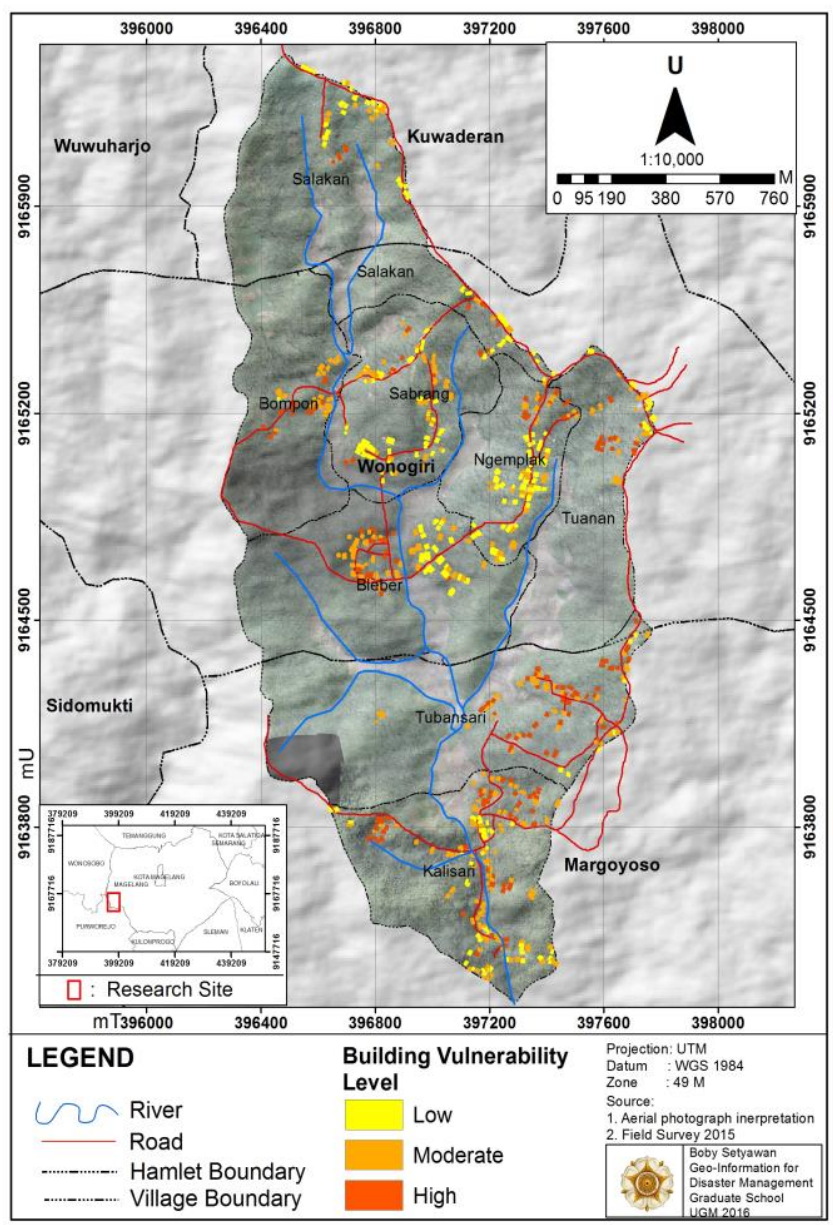

Fig. 4. Building Vulnerability to Landslide Map.

\section{CONCLUSIONS AND SUGGESTIONS}

Based on the objectives and the result about the building vulnerability analysis through the $2 \mathrm{D}$ small format aerial photo interpretation, here are the conclusions of this research:

- The landslide inventory analysis found about 34 landslides occurred in the research location. Most of the landslide types are Rotational slide. Active landslide 
triggered by its association with river and anthropogenic activities.

- The parameter used to assess the building vulnerability are the building structure, roof material, wall material, building position from the slope, building orientation from the slope, and building regularity form. The building identification used color, form, and association as the interpretation key.

- The result of the building vulnerability assessment is shows that The high vulnerability levels was covered $185(25 \%)$ buildings. The moderate levels was covered $331(45 \%)$ buildings. The low levels was covered 217 (30\%) buildings.

- Building vulnerability was broadly influenced by the position of the buildings from the slope. Building association to slope is the main triggering factor in building damage when the landslide occurs.

The analysis of building vulnerability in this research was conducted through the interpretation of small format aerial photo in Bompon Catchment. Bompon catchment was 90\% covered by dense vegetation. Some buildings are impossible to identified, because it was coffered by the dense vegetation. The interpretation mistaken of each building parameters also possibly occur. That was the limitation of this research. Considering that condition, it is necessary to conduct an advance research with an intensive field survey on each building to generate more accurate result.

\section{REFERENCES}

[1] A. Saputra, 2012, "Pengurangan Risiko Gempabumi Melalui Evaluasi Bangunan Tempat Tinggal dan Lingkungannya di Kecamatan Pleret Kabupaten Bantul", Tesis: S2 Geo-Informasi Universitas Gadjah Mada.

[2] B. M. Muis, 2012, "Tingkat Risiko Bencana Longsor Lahan Berdasarkan Aspek Kerentanan dan Kapasitas Masyarakat di DAS Tinalah, Kulonprogo, Propinsi DIY”, Tesis: S2 Magister Pengelolaan Pesisir dan Daerah Aliran Sungai Universitas Gadjah Mada.

[3] C. J. Van Westen, , van Asch, T.W.J., Soeters, R., 2005, "Landslide hazard and risk zonation-why is it still so difficult?", Bulletin of Engineering Geology and the Environment Volume 65, Issue 2, pp 167 184.

[4] E. M. Astuti, , 2011, "Analisis Risiko Tanah Longsor Desa Tieng Kecamatan Kejajar Kabupaten Wonosobo", Tesis: S2 Geo-Informasi Universitas Gadjah Mada.

[5] H. Frick, , 1997, "Pola Struktural dan Teknik Bangunan di Indonesia. Suatu Pendekatan Arsitektur Indonesia Melalui Pattern Language Secara Konstruktif Dengan Contoh Arsitektur Jawa Tengah”, Yogyakarta: Kanisius.

[6] J. C. V. De León, 2006, "Vulnerability a Conceptual and Methodological Review, Studies of the University": Research, Counsel, Education Publication Series of UNU-EHS No.4/2006.

[7] M. Motamedi, 2013, "Quantitative Landslide Hazard Assessment in Regional Scale Using Statistical Modeling Techniques”, UMI dissertation publishing.
[8] N. A. U Maitri, 2013, “Analisis Risiko Bencana dan Mitigasi Longsor Lahan di Kecamatan Sukasada, Kabupaten Buleleng Bali (Kasus Longsor di Sepanjang Jalan Menuju Kawasan Wisata)", Tesis: S2 GeoInformasi Universitas Gadjah Mada.

[9] U. M. K. Eidsvig, A. McLean, B. V. Vangelsten, B. Kalsnes, R. Ciurean, L. Argyroudis, S. Winter, M. G. Mavrouli, O. C. Fotopoulou, S. Pitilakis, K. Baills, A. Malet, J. P. Kaiser, G. 2014, “Assessment of Socioeconomic Vulnerability to Landslides Using an Indicator-Based Approach: Methodology and Case Studies", Bull Eng Geol Environ 73:307-324. 